\title{
垂直加熱平板列まわりの自然対流の流動と伝熱
}

\section{Fluid Flow and Heat Transfer of Natural Convection around an Array of Vertical Parallel Plates}

\author{
正 三角利之（鹿児島高専） ○学 蒲池雅樹（鹿児島高専） 正 北村健三（豊橋技科大） \\ Toshiyuki MISUMI ${ }^{1}$, Masaki KAMACHI ${ }^{1}$ and Kenzo KITAMURA ${ }^{2}$ \\ ${ }^{1}$ Dept. of Mech. Eng., Kagoshima Nat. Col. of Tech., 1460-1 Shinko, Hayato-cho, Aira-gun, Kagoshima 899-5193 \\ ${ }^{2}$ Dept. of Mech. Eng., Toyohashi University of Technology, Tempaku-cho, Toyohashi, Aichi 441-8580
}

\begin{abstract}
Natural convective flow and heat transfer around a row of vertical heated plates were investigated both analytically and experimentally. Main concerns are directed to an effect of plate numbers on the fluid flow and heat transfer around the plate arrays. In order to simulate the flow and temperature fields around the rows of plates, full elliptic equations for the momentum and energy transport were solved numerically using the computational domain that encloses the whole plates. The results showed that the present elliptic analysis well predicts the plume interaction and also the local heat transfer coefficients of the plates. The results also depict that the velocity profiles and induced flow rates in between the pairs of plates depend strongly on the numbers and situations of the plates. This also results in marked differences in the local heat transfer coefficients of the plates.
\end{abstract}

Key Words: Heat Transfer, Natural Convection, Plume Interaction, Vertical Plates, Electronics Cooling

\section{1. 緒 言}

垂直な加熱平板が同一水平面上に複数枚，等間隔で分散 配置され, 自然対流により冷却される体系は, プリント基 板の冷却やプレートフィン型熱交換器等で見られる工業的 に非常に重要な体系である.このため平板列まわりの自然 対流に関しては, 現在まで数多くの研究 ${ }^{(1),(2)}$ がなされてい る. しかし, それらの研究は, 平板列中央に置かれた平板 の熱伝達率を測定したものや, 平板列中の任意の 2 平板で 囲まれた垂直加熱流路を対象に数值解析を試みたものがほ とんどである. しかし, 実際に平板列まわりの流れを可視 化してみると, 各平板から立ち昇るプルームは互いに寄り 集まり，千渉する．この干渉によって，平板列の伝熱・流 動特性は, 平板の枚数や平板の置かれた位置によって大き く変化することが予想されるが，その詳緔は不明である. そこで本研究では, 平板の枚数および間隔を系統的に変化 させた場合について, 実験および数值解析を行うことによ り，平板列まわりの流動・伝熱の詳細を探ることにした.

\section{2. 解析および実験方法}

本解析で取り上げた体系および境界条件を図 1 に示す. 表裹面が一様な熱流束 $q_{w}$ で加熱された長さ $L$, 厚さ $t$ の平 板が, 温度 $T_{\infty}$ の静止水中に, 間隔 $b$ 隔てて設置されてい る場合を想定する. 平板列全体を内包する計算領域を設定 し，座標 $x, y$ および速度 $u, v$ をそれぞれ図のようにとる. 流れは層流 2 次元かつ非圧縮とし, 重力項中の密度 $\rho$ 以外 の物性值を一定と仮定し, 楕円型の運動量, エネルギー式 を差分近似して数值解析を行った. これら対流項の差分に は 3 次精度の風上差分を, それ以外の項の空間差分には 2 次精度の中心差分を用いた. また, 時間積分にはSMAC 法 を用いた.解析結果と実験值を同一条件下で比較するため, 解析, 実験とも加熱平板の長さ $L=100 \mathrm{~mm}$, 厚さ $t=2.5 \mathrm{~mm}$, 熱流束 $q_{w}=2000 \mathrm{~W} / \mathrm{m}^{2}$ とした. また, 平板の枚数を $N=2 \sim$ 5 枚, 間隔を $b=3 \sim 20 \mathrm{~mm}$ の範囲で変化させた.

次に, 実験装置であるが, 平板の両表面にステンレス箔 ヒータを貼り付け，このヒータに交流を通電することによ り, 等熱流束条件で加熱した. 体系を 2 次元とするため平 板列の両側面に側板を設け，この側板に等間隔に溝を切り 加熱平板を差し込んだ．試験流体には常温の水を用い，局
所熱伝達率の測定と，染料および粒子懸濁法による流れの 可視化を行った.

\section{3. 実験結果および考察}

3.1 平板流路内の流動特性 まず, 複数平板列の各流 路内に誘起される自然対流の主流方向速度分布を解析によ り求めてみた. その代表的な例として, 平板枚数 5 林, 平 板間隔 $b=10 \mathrm{~mm}$ の結果を図 2 に示す.この図は左外側流路内 の速度分布を示したもので, とくに周囲流体が左右非対称 な速度分布で流路入口 $(X=0 \mathrm{~mm})$ に流入している結果が注目 される. また, この速度分布は下流に向かって一旦凸型と なり,さらに下流では $\mathrm{M}$ 字形の分布へと変化し，これに伴 って速度分布の非対称性が徐々に解消されていくことが分 かる。なお， 5 枚平板列の内側流路入口においても外側流 路と同様, 非対称な速度分布で周囲流体が流入することを 確認した。これらの結果は, 少なくとも 5 枚程度の平板列 では, 各流路内の流れに周期性が成り立たないことを示し ており, 重要な結果と思われる.

以上の速度分布を基に, 各平板流路内の平均流速を求め た結果を図 3 に示す. 図 3 には, 種々の平板枚数 $N$ につい ての結果を記したが，いずれの枚数に対しても，平均流速 は間隔 $b=10 \mathrm{~mm}$ 付近で極大值を示すことがわかる. また, 平 板間隔が同じ場合，平均流速は平板枚数の増加と共に高く なること, とくに 4 林, 5 枚平板列の場合には外側流路よ

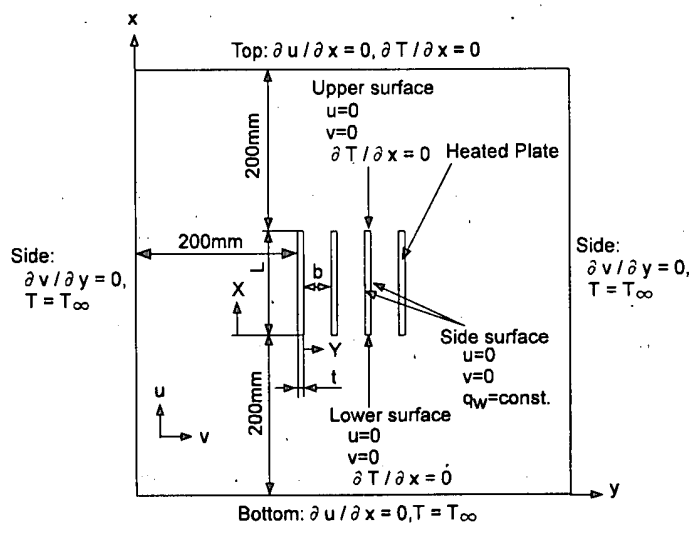

Fig. 1 Analytical domain and boundary conditions 


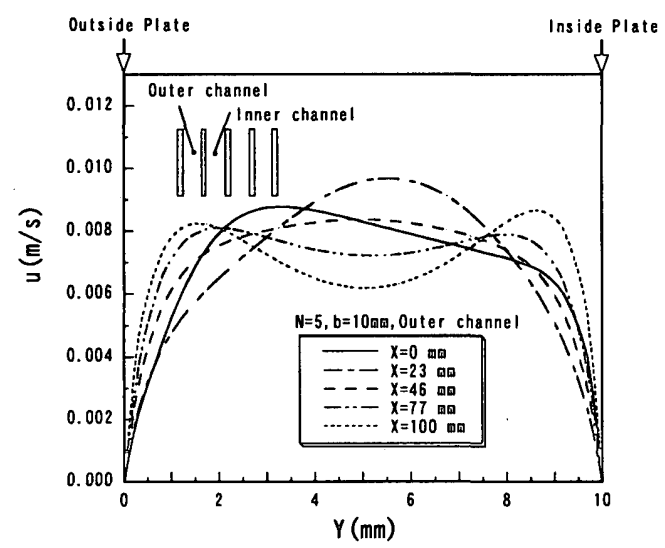

Fig.2 Streamwise velocity distribution within five plates

り内側流路の方が，流速が高くなる結果が注目される.

では何故このような流速 (流量)の差が生じるかという問 題であるが，平板枚数を順次増加させた場合について，各 流路中心線上の流体の圧力分布を解析により求めた結果を 図 4 に示す. 図 4 の縦軸には静圧からのずれの圧力 $P^{*}$, 横軸には流路入口からの距離 $X$ をとっている. 図 4 から, 流路出口における圧力は周囲流体圧力よりも低くなってい る. 平板列上方のプルームの干渉は, この領域の圧力差に よりプルームが周囲から押されるために生じるものである が, この負圧の程度は平板枚数が増えるほど顕著となり, またとくに 4 枚および 5 枚平板列では外側流路よりも内側 流路の負圧が大きいことがわかる.この負圧に伴ってより 多くの流体が流路内に誘引されるため, 上述の差が生じた と考えられる。

3.2 平板列の伝熱特性 つぎに, 上述した各平板流路 内の流動状況の差が, 平板まわりの伝熱特性にごのように 影響するか検討してみた。 一例として，5枚の平板を間隔 $10 \mathrm{~mm}$ で設置した場合について, 各平板表面の局所熱伝達率 を解析および実験から求めた結果を図 5 に示す. 局所熱伝 達率は平板前半部 $(X<50 \mathrm{~mm})$ において, 左から 2 枚目の左 側表面で最も高く，ついで中央平板，2枚目右側， 1 枚目 平板外側, そして 1 枚目平板内側の順に低下していくこと がわかる. 一方, 平板後半部での熱伝達率は, いずれの平 板もほほ等しい值を示している.これらの結果および平板 列まわりの流れの可視化結果から, 周囲流体が平板に向か って流れ込む，平板列の外側を向いた面では熱伝達率が顕 著に高くなり, 逆に, 周囲流体が迁回する平板列の中心側 を向いた面で熱伝達率が低下することがわかった.最後に, これらの局所熱伝達率を基に, 各平板の平均熱伝達率を算 出した結果を図 6 に示す. 図 6 より, まず平板列の最外側 表面の平均熱伝達率は, 図中実線で示した単独平板の值に ほほ一致することがわかる. 一方, これ以外の表面の熱伝 達率は, いずれも間隔 $b=5 \mathrm{~mm}$ 付近で極大值を示すことがわ かる. また, 間隔の狭い $b=3 \mathrm{~mm}$ では, 各表面の平均熱伝達 率はほとんど一致しているのに対して，平板間隔が広くな るに従って各面間の差が顕著になり, とくに最外側平板裏 面での熱伝達率が急激に低下する結果が注目される.

\section{4. 結 言}

本研究では，両面が等熱流束条件で加熱された垂直平板 を同一水平面上に等間隔で複数枚設置した場合について， 平板列まわりの自然対流の伝熱・流動特性を数値解析およ び実験の両面から探った. その結果, 平板列まわりの伝熱・ 流動特性は，平板間隔だけでなく平板の枚数や平板の置か

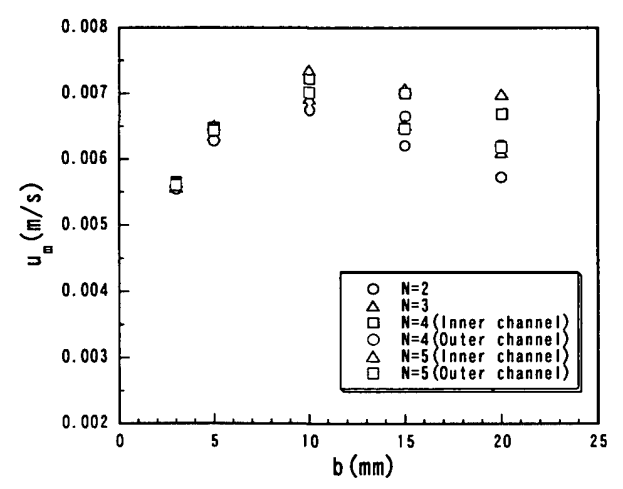

Fig.3 Mean streamwise velocities within rows of plates

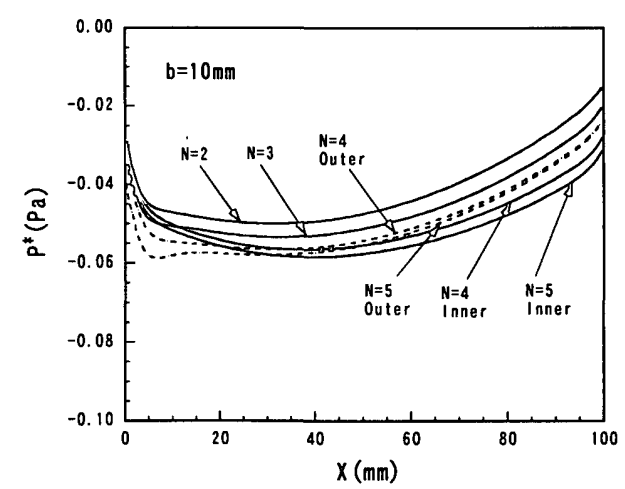

Fig.4 Pressure distribution at the center of channels

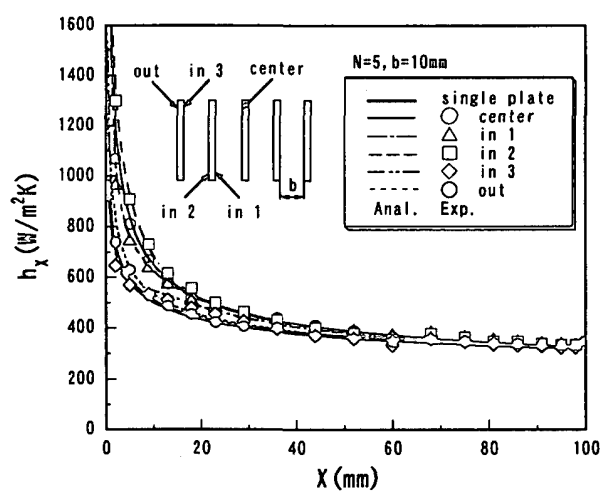

Fig. 5 Local heat transfer coefficients of plate arrays

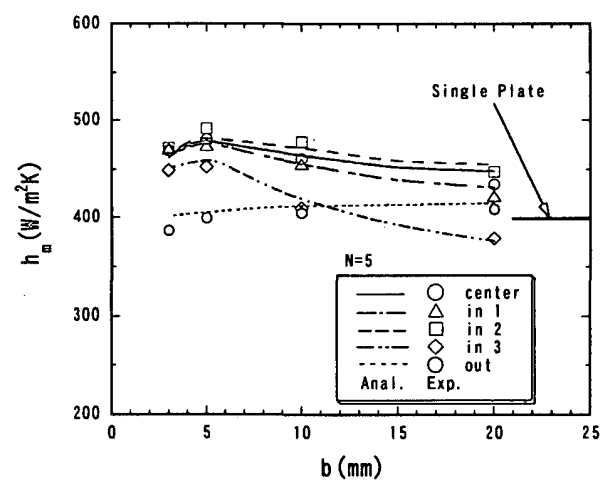

Fig.6 Average heat transfer coefficients of plate arrays

れた位置により大きく変化することが明らかになった 文献

（1）相原利雄, 伝熱工学の進展, 4 (1976)，119-228, 盖賢堂.

(2) O'Meara,T. and Poulikakos,D., Int.J. Heat Fluid Flow, 8-4 (1987), 313-319. 